\title{
A New Method for Growing Hydroids in Small Aquaria by means of a Continuous Current Tube.
}

\author{
$\mathrm{By}$ \\ Edward T. Browne. \\ (University College, London.) \\ With one Figure in the Text.
}

THE simple piece of apparatus, to which I give the name "Currenttube" was made last year in the Marine Laboratory at Plymouth. I designed it especially for growing Hydroids, and for them it has proved to be a success; but it should also be useful for other fixed organisms, such as sponges, polyzoa, and ascidians.

The previous methods which I had used for growing Hydroids in bell-jars or small aquaria never gave complete satisfaction. Occasionally a success was recorded, but there were too many failures, which frequently involved a great waste of labour.

A Hydroid colony when it has an ample food supply grows at an astonishingly rapid rate. I will give as an example of this the growth of Syncoryne eximia in one of my bell-jars at Plymouth in September, 1897.

The colony was taken on September 14th, and suspended in a belljar with one of its branches touching the glass. This branch sent out a shoot which attached itself to the glass and became converted into a stolon. The growth of the stolon and its lateral stolons or branches was measured and sketched daily from September 18th to 23rd, and on the 27 th.

On September 18th the stolon was $14 \mathrm{~mm}$. in length and had no lateral branches. Nine days later (September 27th) the main stolon measured $77 \mathrm{~mm}$. in length, and its numerous lateral stolons or branches measured altogether $500 \mathrm{~mm}$. These measurements excluded the short stalks of the hydranths, which were then seventyseven in number. During the same period a second stolon came off from the old colony, and on September 27 th it measured $70 \mathrm{~mm}$. in 
length and its branches $72 \mathrm{~mm}$. The total amount of new growth in the part of the colony under observation amounted to $773 \mathrm{~mm}$. (34 inches), and ninety-nine hydranths in thirteen days.

The rapid growth of this colony was due to a splendid food supply. The hydranths like large copepods, especially the oily Calanus, and there were no difficulties in obtaining a large supply almost every day. To give the hydranths every chance of catching the copepods, the side of the bell-jar to which the colony was fixed was placed facing a south window, but screened from direct sunlight, and only those copepods which are attracted by a strong light were put into the bell-jar. Consequently the copepods spent the day knocking their heads against the glass in the neighbourhood of the hydranths, and many got too close and were captured. During daylight the copepods usually kept near the surface and followed the course of the sun, but at night they could be brought amongst the hydranths by turning a strong beam of gaslight on to the colony.

I have frequently tried to grow Bougainvillia and some other Hydroids on the system described for Syncoryne, but have never met with a real success. A short stolon would run along the glass and a few hydranths would appear, but they remained in a diminutive condition. The new growth lacked vigour, which was evidently due to the want of food. Although there were plenty of copepods in the bell-jar the hydranths rarely caught them.

The tendency of the copepods to congregate within a small area was not always favourable to the colony, as the zone of the copepods did not always correspond with that of the colony. The introduction of the "plunger" system into bell-jars (described in this journal by the author in 1898) also proved useful for the growing of Hydroids. The currents which the plunger created helped to distribute the copepods more evenly in the water, and other species of copepods which are not attracted by light could be utilized for a food supply. The plunger in its journeys up and down a bell-jar does not set up a current in one direction, but in different directions, so that the copepods are carried hither and thither. It was the quick-changing direction of the current that frequently prevented the hydranths from holding their prey. One current carried a copepod upon the tentacles of a hydranth, and, before the tentacle responded to the touch, another current coming from a different direction would sweep the copepod away.

It must be borne in mind that the number of copepods or the quantity of plankton which can safely be placed into a bell-jar is strictly limited. Overcrowding soon leads to a heavy death rate, and ultimately to the fouling of the water. If copepods are being used 
as food supply for Hydroids, then diatoms and other microscopic organisms should be present in the water for the copepods to feed upon. The constituents of the plankton require careful adjustment, and the whole must be kept in a perfectly healthy condition. There should always be a reserve of food in the bell-jar to carry over days of bad weather at sea and other misfortunes.

Hydroids certainly keep in better condition and live longer in a belljar with the water in constant motion than in perfectly still water. They are accustomed in the sea to a current running in a definite direction and carrying along plankton, from which they select their food. In the sea the current is ever running, always fresh and aerated, and always carrying new plankton. The successful rearing of Hydroids in a few gallons of water depends greatly upon imitating, as closely as possible, the natural conditions under which they live in the sea. The current-tube imitates fairly closely these conditions. The Hydroid is placed in a glass tube through which flows a constant current of aerated water carrying along with it the plankton in the bell-jar.

Description of the current-tube. The power for producing the current within the tube is compressed air. It does not matter by what method the air is compressed, provided that the pressure is kept fairly constant and the air is clean and pure. The latter condition is important, as a considerable quantity of air passes through the seawater in the course of a day. The supply should be drawn from outside of a building, and then washed or filtered to remove the dust. The air-pump used in the Laboratory at Plymouth is a form of Sprengel's pump, made of metal, and obtainable for about ten shillings.* It is a remarkably cheap, but very efficient piece of apparatus.

I shall describe the current-tube as it was originally made by me. (Fig. 1). Modifications in size and shape will no doubt be introduced later on to meet special requirements.

$A$ is a glass tube, $32 \mathrm{~mm}$. in diameter and about $200 \mathrm{~mm}$. in length. At the lower end a bored cork is inserted, into which is placed the narrow glass tube $B C D$, having an internal diameter of about $4 \mathrm{~mm}$. $B C D$ is an ordinary T-tube, with one end $(D)$ reduced in length, one end $(B)$ made $U$-shaped as figured, and the third end $(C)$ remaining perfectly straight. To $D$ is attached by a short piece of rubber-tubing the long glass tube $E$, the length of which depends upon the depth of the bell-jar. The next step is to tie a piece of string round the tube $A$ near the top, and lower the current-tube into the bell-jar. The string attached to $A$ is made fast to the top of the bell-jar, and adjustments made to hold $A$ in an upright position.

* The pump is supplied by Anton Skell, Zinzendorfstrasse 34, Dresden. 
A tall bell-jar was used, about 20 inches $(50 \mathrm{~cm}$.) in height and 8 inches $(20 \mathrm{~cm}$.) in diameter. The top of the tube $A$ was about

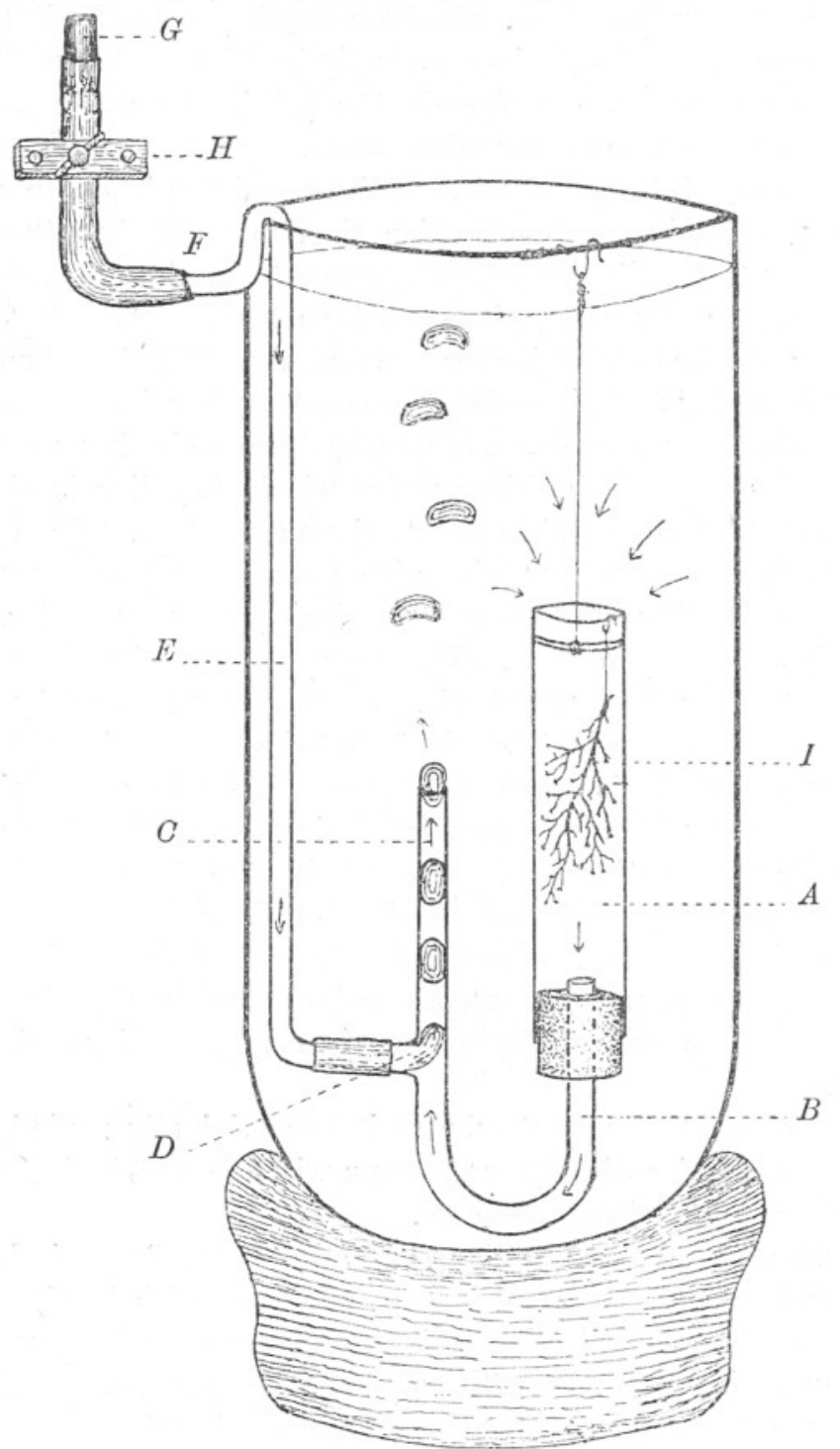

Fig. 1.

Diagram of the current-tube inside a bell-jar.

9 inches $(23 \mathrm{~cm}$.) below the surface of the water, which was about an inch below the top of the bell-jar.

After adjusting the current-tube, fill the bell-jar with sea-water, and connect tube $E$ at $F$, with rubber-tubing, to the pipe $G$, supplying 
the air from the pump. On the rubber-tubing near $F$ should be fixed a screw compressor $(H)$ to regulate the flow of air. On allowing the air to enter at $F$, it forces the water out of tube $E$ down to $D$, and as the air enters tube $C$ it breaks into bubbles, which pass up tube $C$ and float to the surface. Between every two air-bubbles there is a short column of water. The driving of the water out of tube $C$ by the airbubbles produces an in-draught of water through tube $A$. As the airbubbles follow one another in rapid succession, there flows down tube $A$ a good current of water.

The Hydroid $(I)$ is suspended inside tube $A$ by a silk thread attached to a small glass hook, which hangs over the top of the tube; and the copepods, diatoms, etc., are put into the bell-jar.

As the current through tube $A$ mainly draws from the upper part of the bell-jar, it is best to keep the top of the tube as low down as possible. The continuous stream of air which bubbles out of tube $C$ not only aerates the water, but sets up a current inside the bell-jar and produces a good circulation. It is therefore advisable to keep the top of tube $C$ low down. This circulation is beneficial to the plankton, and also carries it within the reach of the stream drawing in to tube $A$. The stream of air-bubbles is in another way of great service. Their continual breaking at the surface prevents the formation of the scum, chiefly due to bacteria, which gradually accumulates in small aquaria to form a thick, dirty surface film. This film, when once formed, is difficult to remove, and is often harmful to the inhabitants of an aquarium.

So long as the water in a bell-jar keeps quite clear there is no necessity to completely change it. I usually siphon off about half a gallon twice a week and fill up with very clean water.

The growth of Bougainvillia muscus in a current-tube. On November 6th a small bush-like colony of Bougainvillia muscus, about $20 \mathrm{~mm}$. in length, was suspended inside a current-tube with the root of the colony touching the glass. The colony had a few short stolons growing out from near the distal ends of the branches. It was for observations upon the growth and function of these stolons that the Bougainvillia was placed in the tube.

Soon it was apparent that Bougainvillia liked its new surroundings. The hydranths kept fully extended, and their stomachs were seldom empty. The stolons greatly increased in number and in length, some hanging down 15-20 mm. A few developed, here and there, solitary diminutive hydranths, but there were no signs of active budding of hydranths. The activity of the colony was directed into a stolon which came off from near the root and was able to attach itself to the glass of the tube, along which it grew at a 
great rate, sending out lateral stolons and quickly producing large hydranths.

A most fascinating and beautiful sight was to see the colony at night under a low-power lens, illuminated by a strong light against a black background, and to watch the fate of the copepods as they passed down the tube. Usually the copepods on entering the tube either were carried clear of the colony, or going among the hydranths succeeded in escaping into the narrow tube, and then were rapidly ejected along with the air-bubbles. As the current through the tube was fast enough to pass the whole of the water in the bell-jar through several times during the day, the copepods, which escaped on their first round were liable to a few more passages of the tube, until their fate was settled by the hydranths which had recently emptied their stomachs.

On watching the copepods passing through the tube, it was clearly seen how a steady, continuous current in one direction was of advantage to the hydranth in securing a copepod. A copepod would be seen to drift on to the expanded tentacles. If at the moment of touching the copepod gave a jump it usually got away, but occasionally the jump was delayed too long, and pressed by the current against the tentacles, it remained just long enough to be secured.

As my stay at the Laboratory terminated on November 17 th, I was only able to watch the growth of the colony for eleven days, and during that period the new growth far surpassed that of any Bougainvillia which I had previously tried to grow. Mr. L. R. Crawshay most kindly took charge of the colony, and I am able to give a further account of the growth from his letters to me.

Letter dated November 30th:- “ The colony has been kept well fed with copepods every day. The air-pump continues to work successfully, so that the food supply has been continuous. The growth of the colony has consequently been very rapid, more especially, or almost entirely, over the basal stolon, which by yesterday had extended over the whole length of the tube, lining the main expanse of the interior surface. Young polypes have grown out from this surface at every part, and almost without exception at or near the points where branching of the stolon occurs. But so far as I have observed the polypes are simple; there is no tendency to a treelike expansion anywhere. The parent part of the colony has not developed."

"The colony has developed enemies; from what source I know not, whether from veligers in the tow-nettings or from original infection. Three days ago three minute nudibranchs were first observed browsing on the hydranths, which proved to be Tergipes despectus. Yesterday 
the number had increased to six, and now the survival of the colony is threatened by about thirty capsules of their spawn deposited all over it."

Letter dated December 18th :- "Shortly after my last letter to you, a day or two only, it was evident to me that the six Tergipes were having it all their own way. They had stripped the whole stolon area of almost every visible polype, and had, moreover, simply plastered the same with spawn, containing, I should say, thousands of their embryos. I therefore took out the tube and removed the Tergipes, and thoroughly cleaned out the bell-jar before returning the Hydroid colony. The effect was very marked. In about two days the polypes sprung up again in all directions, and the stolon continued to form a closer network inside the tube. But it is even now to all intents and purposes a creeping colony. The first show of arborescent growth occurred inside the tube. This happened after the stolon had reached the summit of the tube and ramified over the edge. A few days ago a similar branching growth appeared outside the tube at one spot. But this is quite insignificant, with only about three polypes, and no more than $10 \mathrm{~mm}$. in height."

"A new source of obstruction has arisen in the form of a brown diatom, which in the past few days has come to infest almost the whole interior of the tube."

Early in February, 1907, I heard that the colony was still alive, but owing to the intermittent failure of the air-pump and the scarcity of copepods the colony had not put forth much new growth.

In March the growth of diatoms and a small alga (Ectocarpus) inside the tube was slowly choking the colony. A few vegetarian molluses were placed on the tube to browse on the algæ. They did more than was expected of them in cleansing the tube. Within a fortnight of their introduction the encrusting mass of diatoms, etc. lining the tube broke away in large flakes, perhaps due to a poison secreted by the molluscs, and carried away at the same time the stolons to such an extent that the whole colony was destroyed.

The successful growing of Bougainvillia is not altogether due to the advantages of the current-tube, but greatly also to the personal attention which Mr. Crawshay bestowed upon the colony. I sincerely thank him for the interesting letters from which he has allowed me to quote.

I am also greatly indebted to Dr. Allen. It was during the preliminary testing of his air-pump that the current-tube was designed. $\mathrm{He}$ at once most generously gave me the use of the pump, and took a very active interest in the starting of the apparatus and in the welfare of the colony. 